UDC 130.123

LBC 87.22

\title{
DEMYSTIFICATION OF THE IDEA OF TRANSCENDENT GOD OR IS IT POSSIBLE TO UNITE RELIGION AND SCIENCE?
}

\author{
Andrew V. Gizha \\ Donetsk National Technical University, Donetsk
}

\begin{abstract}
The article considers the historically determined relation of two essential forms of social consciousness, science and religion. The condition for the productivity of its disclosure is going beyond the limits of a simple and non-reflective preference for a state of faith or scientific knowledge. It gives the opportunity of formation of veracious cognitive discursive-conceptual practice. First of all, it presupposes philosophic formulation that is a non-idealized approach to comparative-analytical view on the existence of science and religion as social life phenomena. Secondly, it needs a valid socio-culturally determined essential basis for this or that view on a given relation. Thirdly, it reaches its determinacy in the desired transformation of socially determined types and ways of perception. Preliminarily, religion and science are to be determined in their principal autonomy. In sociohistoric regard, religion is the basis and vital condition for the appearance of the archaic patrimonial form of the social. Science, starting from the era of Greek natural philosophy, asserts such a cognitive dialectic of concepts, where there is no place for external compulsion, but the sphere of freedom of the thinking individual is formed. In both cases, we observe the output into limiting statement of sensually-material or conceptual-ideal regards. Their further existence requires well-known separation of the spheres of the essential presence of science and religion. Also, it is necessary to preserve the religious sense of the cosmically-generic significance of man with the retention of humanity as its immanent quality, but without the Old Testament cosmologically-oriented traditions. Natural science, on the other hand, establishes a monopoly on true knowledge of nature, society, history, and thought, without, accordingly, the positivist limitations of its own premises. The result of these differentiations will be the procedure of dearchaization of theological thought, its establishment in the perspective of the predominant moralethical and subject-rationalistic orientation.
\end{abstract}

Key words: religion, science, deconstruction, archetype, unconscious, rationalism, criticality, God.

УДК 130.123

ББК 87.22

\section{ДЕМИСТИФИКАЦИЯ ИДЕИ ТРАНСЦЕНДЕНТНОГО БОГА, ИЛИ ВОЗМОЖНО ЛИ ОБЬЕДИНЕНИЕ РЕЛИГИИ И НАУКИ?}

\author{
Андрей Владимирович Гижа \\ Донецкий национальный технический университет, г. Донецк
}

\begin{abstract}
Аннотация. Рассматривается исторически определенное отношение двух существенных форм общественного сознания, науки и религии. Условием продуктивности его раскрытия является выход за пределы простого и нерефлексивного предпочтения состояния верования либо научного знания. Это дает возможность формирования истинностной познавательной дискурсивно-понятийной практики. Она предполагает, во-первых, выработку философского, то есть деидеологизированного подхода к компаративистски-аналитическому рассмотрению бытийности науки и религии как феноменов общественной жизни, во-вторых, выявление действительного, социально-культурно установленного сущностного основания того или иного ви́дения указанного отношения, и, в-третьих, достигает определенности в желаемой трансформации общественвозникновения архаически родовой формы социального. Наука же, начиная с эпохи греческой натурфилософии, утверждает такую познавательную диалектику понятий, где нет места внешнему принуждению, но
\end{abstract}


образуется сфера свободы мыслящего индивида. В обоих случаях происходит выход на предельные констатации чувственно-материального или понятийно-идеального планов. Дальнейшее их существование требует известного разграничения сфер сущностного присутствия науки и религии. При этом необходимо сохранить религиозное ощущение космически-родовой значимости человека с удержанием человечности как его имманентного качества, - но без ветхозаветных космологически ориентированных преданий. Естественнонаучное же познание закрепляет монополию на истинностное знание природы, общества, истории и мышления, без, соответственно, позитивистских ограничений собственных предпосылок. Следствием проводимых дифференциаций станет процедура деархаизации теологической мысли, ее установление в ракурсе преимущественной морально-этической и предметно-рационалистической направленности.

Ключевые слова: религия, наука, деконструкция, архетип, бессознательное, рационализм, критичность, Бог.

\section{Специфика религиозной, научной и философской форм деятельностного понимания}

Факт реставрационного возобновления в последние 30 лет на просторах русской культуры социально-личностного опыта православия и явно демонстрируемая при этом устойчивая и длительная государственная поддержка на самом высоком властном уровне позволяет не только провести констатацию некоего ренессанса декларируемых христианских добродетелей, но и требует возобновления философски-концептуального, просвещенческого продумывания места и роли религии в мире и истории, ее сущностной определенности, а также отношения к науке как установившейся мировоззренческой альтернативе. Научный дискурс здесь претерпевает заметную мировоззренческую нивелировку в сравнении с еще недавним периодом его полного, прямого или косвенного, доминирования в сфере общественного сознания. Одновременное усиление религиозности носит выделенный официозный характер и в этом качестве хорошо коррелирует со сходным этапом во второй половине XIX в., когда наметилась «тенденция религиозного оживления, зачастую принимавшая вид фундаменталистской и утилитаристской позиции, характерной как для многих (но не для всех) представителей церковной иерархии и авторитетных "подвижников благочестия"» [Антонов 2015, 111]. Результатом указанной нивелировки научного дискурса является плохо завуалированная ситуация понятийно-мировоззренческого смещения философских рассуждений в сторону религиозной иррациональности. Л.А. Боброва, делая обзор материалов конференций, посвященных диалогу религии с наукой и философией, зак- лючает о существовании тенденции «развивать гуманитарные науки на основе православного мировоззрения. Именно в этой органической связи науки, философии и православной религии авторы видят пути выхода из тупиков существования человека в современном мире» [Боброва 2010, 11]. Предлагается, иными словами, некий химерический симбиоз науки и религии, хотя основная демаркация в этом вопросе прочерчена со времен Канта. Но почему надо останавливаться на гуманитарных дисциплинах и не предложить, например, физике ввести догматику Ветхого Завета в ее космологические теории? То, что для естественных наук отчетливо понимается как абсурд, для гуманитарных взглядов с их неотчетливой методологической и фактуальной базой является, зачастую, поводом для произвольных спекуляций. В отечественной традиции постсоветского философствования возник интересный феномен, который можно обозначить как «внелогичный поворот». Он является продолжением общего процесса идеологизации обобщенных суждений, составляющих неотъемлемый сегмент философии обществ с частнособственническим, отчуждающим типом хозяйствования. Так, в А.В. Попов последовательно утверждается, что «объектом науки может выступать только то, что, так или иначе, проявляется в объективной действительности. ....Нематериальный Бог не может... выступать в качестве объекта науки» [Попов 2010, 57]. Однако общим заключением является признание координационно-равноправного отношения науки и религии: «В вопросе о бытии Бога наука и религия взаимодополняют друг друга: там, где заканчиваются познавательные возможности науки, в свои права вступает религия» [Попов 2010, 59]. Этот мировоззренчески бессильный вывод 
является следствием отождествления автором типов высказываний, характерных для теологии и метафизики: «Метафизик и теолог... производят не теорию, а поэзию или миф» [Попов 2010, 57]. Заметим, что автор пользуется методологией логического позитивизма и заранее абстрагируется от действительной философской содержательности, далеко не совпадающей с мифом или поэзией. Близкую по смыслу трактовку отношения религии и науки мы видим у Д.Р. Александера [Александер 2010] и Р. Трига [Триг 2011]. Здесь воспроизводится все та же апелляция к некой «многослойной реальности», о сути которой совершенно ничего не сказано. Триг вообще отводит религии доминирующую роль даже в эвристически-методологическом отношении: «В прошлом именно вера в Бога давала науке твердую философскую основу. Наука стремилась познать мир как божественное творение» [Триг 2011, 296]. Эти суждения могут быть определены как сугубо идеологические, лежащие вне реальной истории и философии науки.

Отдельно выделим не имеющую отношения к научности тенденцию эзотерико-оккультной направленности, получающей сочувственное обсуждение в научной периодике [Меретукова, Чиназирова 2016].

Понятно, что сейчас совершенно нет необходимости заострять дискуссию в богоборческом плане революционного атеизма и видеть в религии исключительно реакционную социальную силу. Более того, здесь, для чистоты рассуждений и их деполитизации, можно вообще исключить атеистические посылки и тем самым вывести обсуждение из неразрешимого тупика взаимного перекидывания оппонентами аргумента первого доказательства. Хотя, конечно, доказывать существование Бога должны именно верующие, а не атеисты - его отсутствие. Здесь уместен пример Б. Рассела с фарфоровым чайником, якобы летающим вокруг Солнца между орбитами Меркурия и Венеры. Доказать, что он есть - дело утверждающего, а вовсе не тех, кто в этом сомневается.

Науку, и, соответственно, научный способ трактовки сущего автор видит как выражение высшего типа рациональности, зрелого этапа ее исторического развития. Наука есть высшая форма институциализованной рацио- нально-познавательной деятельности, сущностно определенной тремя основными признаками. К последним относятся: 1) наличие математически выраженной моделирующей теоретичности, 2) наличие экспериментальной практики и 3) наличие метрологии (измерительной составляющей). Все три компонента научности исследований в совместном применении реализуют возможность достижения логически согласованного, экспериментально удостоверяемого и технически применимого знания.

Религиозный тип (общественного) сознания будем понимать как обоснование и выражение первичной коллективной практики построения человеческой формы индивидуальных и общеплеменных отношений. Этот тип сознания генетически архаичен, т. е. отличается первичностью, и нацелен, во-первых, на обоснование легитимности племенной и, далее, государственной власти, и, во-вторых, на формирование социо-культурного, символического пространства обобщенно интерпретирующей семантики. Религиозные отношения в период формирования древних обществ проходят этап институализации и становятся исторически первой формой духовно-культурного становления сугубо человеческого отношения к миру, расширяющего собственно природные рамки обитания, преобразуя ее в сферу идеально-символического, осмысленного бытия. Соответственно, сущностные признаки в этом случае определяются как введение качеств сакральности (священности предметов и обрядовых действий), жертвенности (общения с богами) и трансцендентной структуры мира. Трансцендентность структуры означает признание наличия внеопытной и непостижимой сферы действительности, обладающей общим регулирующим действием относительно сущего.

Вопрос об этом типе сознания стоит так: воплощает ли он действительно универсальное, внеисторическое выражение онтологических условий жизни человека как такового в его исконной родовой сущности или же мы, напротив, встречаемся здесь лишь с начальным этапом самопознания, имеющего преходящие условия функционирования? Последние в таком случае естественно определяются имеющимся неразвитым сознанием 
человека архаического общества, его кругозором и складывающейся социальной коллективностью с простыми и наглядными механизмами власти и управления. Основным интерпретирующим каркасом здесь служит единственно доступное родовому сознанию наглядное антропосоциоморфное описание и представление. Исключая мистификацию свыше данных установлений, оставляем второй вариант как преимущественный.

Мифо-языческая религиозность безраздельно властвовала в истории до возникновения на периферии Древней Греции, в Милете натурфилософии в конце VII в. до н. э. Новая форма общественного сознания, философия, имеет свои особенности, делающие ее заметно отличной от иных способов и практик бытийствования общественного субъекта. На ней лежит неизменный и нестираемый личностный отпечаток реально пережитого опыта трансценденции, прошедший аналитическое горнило становящегося рационально-понятийного мышления. Зарождается, таким образом, и собственно доказательность рассуждений, их осмысленная последовательность, опирающаяся не на внешний авторитет традиции, а на факт разумности вывода. Рационалистическая аналитичность мысли дополняется критичностью внешней - открытостью рассмотрения любой содержательности, ее логическим перепросмотром и возможностью коррекции либо вообще отказом от нее, и критичностью внутренней, относящейся к формированию личной ответственности высказывающего как говорящего «от себя», как самостоятельной личности, как субъекта мысли.

В философии мы встречаем не только некие «первоощущения бытия», но и их вполне внятный, логически последовательный анализ, имеющий лишь одну предпосылку стремление к истинностности формулируемых трактовок вне каких-либо прагматически-утилитарных предпочтений и ангажирований либо апологий чего бы то ни было. Ни государственная власть, ни ее репрессивный аппарат, ни доминирующие и защищаемые религиозные установки и культы, то есть ничто из сущего, могущее производить силовое давление и принуждение, не влияло на выводы философов помимо тех ситуаций, когда мыслитель по простительной человеческой слабости терял состояние созерцательной объективности. «...Философия открывает человеку убежище, - говорил Ф. Ницше, - куда не проникает никакая тирания...» [Ницше 1994, 20]. Это собственное пространство свободного человеческого бытия, где индивид осуществляет себя как осознанный творец ценностей, смыслов, значений, символов, поведенческих практик. Разум ищет не своего, отмечает Гегель, а истины [Гегель 1974, 80].

Философия реализует собственно рационалистичность в ее высшей и предельно обобщенной форме категориально-понятийной мысли, осуществляющейся в режиме диалоговой самопроверки и не остающейся только лишь в виде некоей абстракции. Конкретная рационалистичность потому и конкретна, что осуществляет переход в свое иное, в материально-духовную практику предметного действия.

В первых же философских школах возникает общая тема развенчания вульгарно трактуемой мифологии как басен и сказок. В достаточно резкой форме достается Гомеру и Гесиоду, да и между собой философы не стесняются в выражениях. Рождается атмосфера общения, которую в наше время назовут «агрессивной интеллектуальной средой», атмосфера бескомпромиссной борьбы идей и мировоззрений.

\section{Деконструкция \\ в античной греческой философии}

Первые мыслители сразу же приступили к процедуре логико-семантической деконструкции религиозно-мифологического сознания, которую как методологическое открытие постмодерна утвердит во второй половине $\mathrm{XX}$ в. Ж. Деррида. В этой задаче по выявлению симптоматики общественных недугов и выправлению положения в сфере сознания, как общественного, так и личного, заключается исторический долг и скромная возвышенность философской деятельности. Коррекция шаблонных представлений, имеющих приоритетное положение в структуре общественного сознания, но являющихся либо суевериями и предрассудками, либо просто выражением застарелого невежества - обязательное дело 
философа, связанное (в идеале) с его бескорыстным служением общему благу.

Первая деконструкция, выполненная раннегреческой философией, проходила в два этапа. Вначале происходила логическая выработка рационалистического канона осмысления того первоощущения единства сущего, которое подспудно несла в себе институциализованная религиозность. В религии единство сущего еще скрыто, оно завуалировано натуралистической формой сложившейся наглядности интерпретаций, неизбежно ведущей к догматизму, косности и разного рода ересям. Философия переводит этот нераскрытый онтологический опыт из неподвижного состояния декларируемой богоданности в объект рефлексии, наделяет его статусом открытого содержания.

Однако первый этап оставляет рефлексию в рамках исходных сложившихся обозначений. Так, Ксенофан выстраивает логическое заключение о боге, противопоставляя его дедуктивно выводимую единственность принятой языческой множественности олимпийских богов. Он не говорит о существовании бога как такового, а только подвергает ревизии расхожие представления о нем. Он, как свидетельствует Псевдо-Аристотель, приходит к обоснованию вечности бога, его единственности, шарообразности, ему не может быть приписан предикат конечности или бесконечности, движения или покоя [Фрагменты... 1989, 160]. Предваряет Ксенофан свои рассуждения характерной предпосылкой - «если это есть», имея в виду бога [Фрагменты... 1989, 160]. После данного гипотетического предположения он развивает, в переложении Псевдо-Аристотеля, логически корректные выводы на тему заявленного объекта, обладающего лишь частичной предикацией. Направленностью дедукции здесь управляет общая трактовка бога (богов) как некоего предельно могущественного мегасубъекта: «божество по своей природе не терпит над собой господства» [Фрагменты... 1989, 160]. Далее Псевдо-Аристотель дает весьма продуманную критику ксенофановым упражнениям в дедукции. Так рождается традиция объективного понятийного анализа, в которой видим отточенную тщательность аргументации, взвешенную критичность и бескорыстное стремление к истинности.
Таким образом, первая форма деконструкции существующей матрицы общественно значимого понимания, выполненная Ксенофаном, далее сама подверглась нормальной рефлексивной процедуре осмысления. Причем эта работа проходила не в контексте возврата к прежним взглядам и ниспровержения ксенофановых суждений, а, напротив, в направлении их усиления и логического выправления. При этом формируется традиция критической перепроверки дедуктивно выполненной всеобщей концептуальности, возникает процедура недогматического свидетельствования бытия в его предельных вариациях и глубинах.

Человек при этом не просто получает нечто готовое к использованию как подарок сущего - такие дары он имел от мироздания на заре цивилизации и культуры в фиксированных формах мифорелигиозной практики - но начинает находить себя как разумное и деятельно осознанное существо, умеющее самостоятельно и без отсылок к непознаваемым факторам осмыслить собственное пребывание и лично-ответственно подойти к познанию мира.

Второй этап деконструкции, устраняющий обыденно-наглядную трактовку мифов как недостоверную для логического опыта разума, проводит ученик Ксенофана Парменид. Он говорит уже не о боге или богах - они присутствуют лишь как метафорическая фигура речи, а прямо излагает онтологическую схематику сущего, получаемую на основе реализации уловленного рационалистического логоса, и развертываемой в аналитике предкатегорий (подробнее см. в работе автора: [Гижа 2018]). Тот опыт выявления верных контуров бытия, который принадлежал религиозным воззрениям, не позволял мышлению начаться в своей стихии, свободно и ответственно. Религиозное первоощущение глубин действительности и его сущностного размаха было как бы предписано индивиду, доверчиво принято им и положено в основание родовой социальности. Греческое мышление зародилось в условиях поистине чудесного сочетания ряда причин и факторов - по отдельности они были у всех народов, но алхимическая трансмутация сознания с выходом на диалектику понятий, произошла лишь в греческих полисах. 
Как бы то ни было, мы фиксируем фактографию истории самосознания. Она заключается в выходе уже первых философских школ на предкатегориальную проблематику, потенциально обладающую устанавливающей силой творения. Философ символически расчерчивает и понятийно утверждает в общественном сознании именно человеческий мир, то есть такое сущее, которое испытало преобразующе-просветляющее воздействие истинностной мысли. Парменид рационально свидетельствует о сущем как таковом, самоубеждаясь в адекватности проводимого понимания. Здесь нет ни грана принуждения, но проводится методологически звучащее предложение думающему субъекту «рассудить многоспорящий довод Разумом...» [Фрагменты... 1989, 296]. Самоудостоверяющая разумность предлагаемой дедуктивной картины определяет зарождение рациональной теоретичности и является предтечей собственно экспериментальной научной практики. Будучи корректно проведенной (непротиворечивой), с явным указанием начальных условий и предположений (Ксенофан: если это есть...), она столь же убедительна, сколь и данные подтвержденной экспериментальной деятельности. Ее можно представить как своего рода теоретическую экспериментальность разума, выходящего к осознанному и проверяемому установлению реальности в ее измерении понятийной и символической устойчивости.

Выделенные два этапа исторически первой формы деконструкции объединены, вопервых, тенденцией логического очищения шаблонных императивов всеобщего, доведением их до формы, позволяющей начать обоснованное и аргументированное онтологическое описание, и, во-вторых, образованием начала этой рациональной формы всеобщего. Так, Парменид употребляет категориоподобные формы термины и выражения - «сущее», «не-сущее», «есть», «было», «быть и не быть», «рождаться на свет и гибнуть бесследно», «перемещаться». Работа с предположениями такова, что их истинность возможна через продуманную аргументацию: «рождение и гибель, - говорит Парменид, - прочь отброшены - их отразил безошибочный довод» [Фрагменты... 1989, 296].
Парменидовское бытие обладает поистине божественной атрибутикой, более того, его описание делает иные обобщенные предположения (либо аксиоматику) излишней, ведь «нет и не будет другого сверх бытия ничего» [Фрагменты... 1989, 297]. Здесь оформляется и начинает долгую историческую работу вторая деконструкция, суть которой заключается в выработке логического канона обобщенных рассуждений, образующих традицию философской концептуальности, включающей и диалог рациональной способности познания с остающимся еще на долгие столетия и даже тысячелетия актуальным религиозным типом сознания. Она продолжается до сих пор, ведя широкий диалог уже не только с одной религией, но и со всеми формами общественного сознания.

Философия и религия, выходя на предельные констатации - в понятии и чувстве прежде всего, - в целях исполнения истинности сказанного и провозглашаемого должны, безусловно, найти точки соприкосновения как в чувстве, так и в понятии. Такая гносеологическая встреча произошла уже в самом начале греческих теоретических изысканий, когда бог и природа (бытие) стали описываться одним набором предикативных определений.

В дальнейшем была распространена пантеистическая практика содержательного растворения бога в природе: либо происходило выявление координационно-сущностных и деятельностно-иерархических связей между богом и природой, либо же осуществлялось наложение описательных терминологических баз, относящихся, соответственно, к трактовке бога и природы.

Обоснованность и осмысленность таких понятийных и смысловых суперпозиций оправдана в той мере, в которой чувство всеобъемлющей сопричастности миру есть искреннее и реально переживаемое содержание, а, соответственно, разумность философской мысли основывается не на плоском схоластическом мудрствовании, но исходит именно из богатого внутреннего опыта интуитивного гуманистического миропознания.

В свою очередь разрыв и взаимная оторванность друг от друга этих оснований живой мысли и духа влечет либо пустую рели- 
гиозную морализирующую демагогию, свидетельствующую о сектантском сознании, либо рассудочный поток иссушающей банальной премудрости, не умеющей связать слово, дело и мысль в одно целое. В первом случае субъект не владеет способностью высказывания на должном уровне конкретной рациональности, предполагающей критическое и ответственное самообоснование. Второй вариант приобрел широкое распространение с началом секуляризации европейской культуры, когда демагоги и начетчики всех мастей повалили в новую область социо-гуманитарных дисциплин, где нет необходимости иссушать свой мозг высшей математикой и непростыми техническими знаниями, но зато есть широчайшая возможность бесконечных спекуляций и умствований с «ученым видом знатока».

Суперпозиция терминологической базы теологии и философии всегда семантически несимметрична и неравноправна. Она имеет сдвиг в ту или иную сторону, выражая, соответственно, теологический либо рационалистический крен. Относительно равновесной позиции удалось достичь лишь немногим мыслителям, имеющим как раз и теологическое знание, и внутренний опыт богоприсутствия, и глубочайшую логически-понятийную способность рационального и трезвого осмысления предельных онтологических констатаций. Излишне упоминать, что в таком случае подразумеваемое методологическое оснащение работает на высшем уровне эффективности. Таков, например, Гегель.

Современная западная общественная мысль отмечает указанное наложение терминологий в специфически психологическом варианте, а именно в подчеркивании факта нарушенной логики, касающемся соотношения веры (религии) и разума (науки). Здесь со стороны исследователей присутствует три позиции: а) утверждение исторического синтеза науки и религии (например, А. Уайтхед [Уайтхед 1990, 242-254], В. Делекруа [Delecroix 2015], Ф. Чарфи [Charfi 2015]), б) выраженного недоумения таким положением дел (Ф. Фрейстеттер [Freistetter web]) и попыткой проблематизировать отношение религии и науки (В. Джолиберт [Jolibert web]), в) активной критики религиозных претензий на всеобщность и апология науки (Р. Факлер [Fakler web], Дж. Брикмонт [Bricmont 2015], Ив Гиндграс (в рецензии: [Truc 2018]), г) взвешенная фиксация существующих позиций, данная в энциклопедических изданиях (см., например: [Cruz web]). И, наконец, отдельно отметим д) выявление злоупотреблений в финансовой сфере в лице фондов, поддерживающих религиозность под видом научности, раскрытых О. Броссо и С. Бодуэном [Brosseau, Baudouin 2016]. Эти авторы отмечают, что «иллюзия того, что в последние годы возник диалог между наукой и религией, поддерживается саморекламой: награды в основном приписываются тем, кто участвует в руководстве деятельностью фонда» [Brosseau, Baudouin 2016]. Можно констатировать, что общественная мысль Запада пока не занята понятийным проведением деконструкции концепта трансцендентного (метафизического в их транскрипции) бога, оставаясь, в основном, в рамках просвещенческой традиции критики религии.

\section{Проблемность формирования терминологической системы языка онтологических установлений}

В философском отношении вопрос стоит о выработке собственного языка упомянутых онтологических ориентиров: или он тяготеет к разработанной схоластами и богословами многовековой традиции богопознания, данной в сложившейся системе обозначений и трактовок, либо же он должен носить преимущественно рационалистический характер категориальных научных форм мысли. Здесь не получится «взять лучшее» от одной и другой системы и неким образом трансмутировать этот квазисодержательный микс в новую парадигмальную установку познания, объявив ее преодолением «односторонности» науки и религии. Такие вымороченные фантастические конструкции появлялись в конце XIX начале XX в. в трудах оккультистов и теософов и выражали только попытки освятить высоким именем научного знания сомнительные построения с претензией на высшее озарение, представить новое религиозное видение как результат работы некоего расширенного и многомерного сознания. Это расшире- 
ние, к сожалению, не было подкреплено ничем серьезным, кроме простых уверений и повторений уже открытого.

Идеальная, содержательно равновесная концепция отношения бога и природы принадлежит Эриугене в его учении о четырех видах (ступенях) бытия: «Мне представляется, что разделение природы по четырем различиям допускает четыре вида: во-первых, творящий и не сотворенный; во-вторых, сотворенный и творящий; в-третьих, сотворенный и не творящий; в-четвертых, не творящий и не сотворенный («О разделении природы» I, 1, 441 В)» [Антология... 1969, 790]. Здесь важно достижение логической исчерпанности перечисленных этапов развертывания форм природного (или божественного) бытия. Она не только полна, но и явно демонстрирует принцип проводимой классификации, который, конечно, можно оспорить, но в данных рамках перечисление проведено безошибочно.

В приведенной картине мировой онтологии замечательна не только ее логика, но и тот гносеологический шаг, к которому она настойчиво подталкивает. Он заключается в упрощении предложенного видения путем вычеркивания из нее фигуры бога как содержательно излишней. Здесь она только дань христианской традиции, но для Средних веков ее упоминание неизбежно для выполнения процедуры общественной легитимации предлагаемой концепции, вписывания ее в принятый в виде необсуждаемой нормы тип всевозможных трактовок и интерпретаций. Такой религиозный канон отвечает начинающейся идеологизации общественного сознания, кристаллизации его в рассудочной схематичности общих догматических положений. В собственном виде идеология обнаружит свое существование в конце XVIII - начале XIX в., но ее преддверие оформляется с зарождением буржуазных отношений еще в недрах феодализма. До этого времени нельзя говорить об идеологии в собственном смысле слова, как это бывает у некоторых исследователей - см., например, статью В.А. Жилиной, где утверждается, что «идеология, без которой немыслима любая историческая эпоха, есть конкретный способ развертывания универсализма культуры в отдельных образованиях»
[Жилина 2009, 20]. Вряд ли правомерно связывать универсализм культуры, определяемый глубоко лежащими и неосознаваемыми в полной мере механизмами символизации и означивания человеческого бытия, с проблемой идеологизации этого бытия, носящей сугубо политический и, более того, совершенно осознанный характер.

Трактовка Эриугены оказалась плодотворной для оживления ранней схоластики и нашла продолжение в работах Давида Динанского (нач. XIII в.), не отвечающих, правда, католическому катехизису, что для нас, напротив, является моментом сугубо положительным. Причем положительность определяется не нашим идейным расхождением с католицизмом, но более глубокими мотивами, а именно - неидеологичностью учения Давида, откуда вытекает возможность его концептуальной истинностности. Давид уттверждал, что «материя - первоначальная, общая субстанция всех вещей. Эта “первоматерия" нераздельна, неподвижна, отличается всеобщностью. Она идентична богу и мировому разуму ("нус") и является единственной подлинной реальностью» [Философская энциклопедия 1960, 425]. «Бог, ум и первая материя - простые реальности и потому не могут иметь никаких отличий. Следовательно, они должны быть субстанциально тождественны. ...Последняя реальность, которая есть одновременно Бог, ум и материя, лучше всего описывается как материя» [Новая... 2010, 577].

Из указанной триады обозначений всеобщего естественным, немистифицирумым содержанием (поначалу, скорее, потенциально) обладает категория материи, которой категория ума (сознания, мышления) противостоит лишь в узких рамках основного вопроса философии в марксистской интерпретации. Понятие бога с развитием рационально-научного познавательного, неидеологизируемого дискурса становится все менее значимым, постепенно превращаясь в необязательную фигуру речи. Ницше отмечал, что «в действительности... между религией и настоящей наукой нет ни родства, ни дружбы, ни вражды: они на разных планетах» [Ницше 1990, 301-302]. Это точная констатация, отражающая как раз сущностное отношение науки и религии. 
Особенности общественного сознания

в его научной и религиозной формах.

Размежевание

соответствующих дискурсов

Мировоззренчески-познавательную трансформацию общественного (родового) сознания, начавшуюся в формах религиозномифологического, архетипического установления, принятого в безусловном, природно-подобном виде, с течением исторического времени удалось довести до его потенциально научного этапа, отличающегося проверяемой истинностью своих представлений. При этом природоподобие общественного сознания мало-помалу сменяется - пусть и не целиком, и не для всех - его исторически осмысленной формой, находящейся, в идеале, в творческом становлении, или, по крайней мере, в стадии разумного и критического обсуждения.

Природоподобие религиозной формы общественного (родового) сознания является своего рода аналогом объективности мира в естествознании и потому вырабатывает весьма устойчивую матрицу мировоззренчески-онтологических ориентаций с предельным охватом содержательности универсума - от моральных инвектив и системы свыше данных запретов до собственно космологической картины мира в его физико-астрономическом срезе. Природоподобие, тем не менее, со временем требует неизбежной смены на действительную, именно природную объективность, находящую свое полное и адекватное раскрытие в научном знании. Ровным счетом те же процессы сокращения поля интересов происходили в философии, которая в начале становления и долгое время потом являлась натурфилософией, соединяющей в нерасчлененном и плохо дифференцированном единстве различные предметные области и способы их осмысления; тут было все: и природа, и общество, и политика, и этика, и логика и т. д. Натурфилософия, пройдя взлет в период ренессансных теоретизирований и фантазий, окончательно сошла с исторической арены с появлением физики как науки в Новое время. Но свое иллюзорное и маргинальное существование она продолжает - или, скоpee, влачит - и в XXI веке.

Столь же конкретно-исторически следует отнестись и к феномену религии, опреде- лив как ее бывшие функции и поле действия, так и текущие реальности. Эти реальности заключаются в том, что космологически-природная сторона целиком и полностью оказывается в ведении научного знания с его формами в виде экспериментального и теоретического естествознания. Это физический строй универсума, где религиозно-церковная догматика требует своего безоговорочного устранения, где она является исключительно личным и внутренним делом ученого-исследователя.

Кроме мира физического, кроме космологически данной Вселенной человеческое бытие конституируется активно творимым миром культуры, выраженном в пространстве смыслов, символов, в высших переживаниях. Религия относится ко второму типу реальности. Она, как символическое обобщение и универсализация архетипических образов, позволяющих испытывать высшие чувства и эмоции, дала возможность человеку на заре истории приобщиться к метапредметным и неутилитарным сущностям, создать образ духовного отношения к миру. Правда, кажущаяся неутилитарность была быстро кодифицирована в форме политического и духовного господства.

Дальнейшее становление человечности выходит на собственную основу, или, говоря языком моральных регуляций - от предписанного закона божьего, от декалога происходит выход на нравственный закон в человеке, определенный его онтологией, и весь дальнейший историко-культурный и цивилизационный путь его развития (или же, напротив, стагнации и распада) является именно личной сферой ответственности и свободы. Ровно так же, как философия не претендует более на монопольное право решать задачи по мироустройству и оставляет за собой именно свое, уникальное поле деятельности, человеческое мышление и сохранение целостности бытия, так же и религиозное сознание должно поступиться потерявшим обоснованность универсальным верховенством и оставаться в собственном пространстве «мер и весов» человечности, (со)хранения полученного изначально сознания целостности и единства с миром. В свою очередь, следует требовать также и от субъекта научного знания понимания меры этого знания. 
Сфера должного науки не предусматривает позитивистского обобщения научных процедур и навязываний псевдоуниверсалистских техносциентистских практик и картин мира. Таким образом, правомерно говорить не об «объединении» науки и религии или о неких мировоззренческих «уступках» со стороны науки, и не вообще о «диалоге» науки и религии, но о насущности трансформации теологического дискурса в направлении снятия мистифицирующих предпосылок догматизированной трансцендентности и вывода ее на формулировки обоснованных, научно рационализированных обобщений социально-исторической и экзистенциальной практики человека. В этом случае демистификация идеи трансцендентного бога означает выход к действительной и центральной проблеме человеческого бытия, не решаемой научным анализом. Она заключается в рационально-философском и общекультурном развертывании темы онтологических основ морали в направлении ответа на кардинальный вопрос: является ли мораль целиком историческим феноменом, либо она имеет также непреходящую составляющую, несущую плохо понимаемую и часто схоластически толкуемую родовую обобщенность. В первом случае феномен морали обладает историко-культурной релятивностью с выраженной детерминантой со стороны утилитарных политико-социальных потребностей. Все эти особенности содержательной зависимости могут быть логически корректно и фактически обоснованно описаны в ракурсе научного анализа. Во втором случае феномен морали признается результатом действия предельно масштабных факторов, связанных с онтокосмическим видением роли и места человека в мире. В обоих вариантах мораль как предмет рассмотрения не проблематизирована. Она подлежит либо естественноисторической регуляции, либо является предметом догматического толкования теологического дискурса. Одно и другое в настоящее время видится как серьезный эпистемический недостаток.

\section{СПИСОК ЛИТЕРАТУРЫ}

Александер 2010 - Александер Д.Р. Модели взаимоотношений между религией и наукой / пер. с англ. А. Фарутина // Страницы: Богословие. Культура. Образование. 2010. Т. 14, № 2. C. 274-286.

Антология 1969 - Антология мировой философии. В 4 т. Т. 1, ч. 2 / под ред. В. В. Соколова [и др.]. М.: Мысль, 1969.

Антонов 2015 - Антонов К. Философская рациональность между религией и наукой: русское гегельянство конца XIX века (Б.Н. Чичерин и П.А. Бакунин) // Государство, религия, церковь в России и за рубежом. 2015. № 4 (33). C. $110-134$.

Боброва 2010 - Боброва Л.А. Диалог религии с наукой и философией (реферативный обзор) // Выхристюк-Андреева И.С. (ред.). Знание и вера в философском дискурсе: Традиции и современность: сб. науч. тр. М.: РАН. ИНИОН, 2010. C. 11-34.

Гегель 1974 - Гегель Г.В.Ф. Речь Гегеля, произнесенная им при открытии чтений в Берлине 22 октября 1818 г. // Энциклопедия философских наук. В 3 т. Т. 1. Наука логики. М.: Мысль, 1974. C. 79-83.

Гижа 2018 - Гижа А.В. Вопрос возникновения философского знания как имманентная проблемность теоретической рациональности // Virtus: Scientic Journal. 2018. № 33, pt. 1. P. 19-24.

Жилина 2009 - Жилина В.А. Онтологический анализ религии в соотношении с идеологическими процессами общественного сознания // Вестник ЧелГУ. 2009. № 18. С. 20-25.

Меретукова, Чиназирова 2016 - Меретукова 3.К., Чиназирова А.P. Паранаучное (эзотерическое) знание как конвергирующий науку и религию феномен и проблема его включения в содержание образования // Хватова С.И. (ред.). Богослужебные практики и культовые искусства в полиэтническом регионе: сб. материалов Междунар. научн. конф. Майкоп: Магарин Олег Петрович, 2016. С. 784-801.

Ницше 1990 - Ницие Ф. Человеческое, слишком человеческое // Ницше Ф. Сочинения. В 2 т. Т. 1 : пер. с нем. М.: Мысль, 1990. С. 231-490.

Ницше 1994 - Ницие Ф. Несвоевременные размышления // Ницше Ф. Сочинения. В 3 т. Т. 2. М.: REFL-book, 1994. C. 7-142.

Новая... 2010 - Новая философская энциклопедия. В 4 т. Т. 1. А-Д. М.: Мысль, 2010.

Попов 2010 - Попов А.В. Вопрос о бытии бога в религии и науке // Система ценностей современного общества. 2010. № 16. С. 56-60.

Триг 2011 - Триг P. Нужна ли науке религия? / пер. с англ. В. Иванова // Страницы: Богословие. Культура. Образование. 2011. Т. 15, № 2. C. 287-296. 
Уайтхед 1990 - Уайтхед А. Избранные работы по философии / пер. с англ. И.Т. Касавина. М.: Прогресс, 1990.

Философская энциклопедия 1960 - Философская энциклопедия. В 5 т. Т. 1 / под ред. Ф.В. Константинова. М.: Сов. энцикл., 1960. С. 425-426.

Фрагменты... 1989 - Фрагменты ранних греческих философов. Ч. І. От эпических космогоний до возникновения атомистики. М.: Наука, 1989.

Bricmont 2015 - Bricmont J. Science, philosophie, religion: quels rapports? // Science et PseudoSciences. 2015. № 314. P. 24-34.

Brosseau, Baudouin 2016-Brosseau O., Baudouin C. La fondation Templeton ou l'imposture du dialogue entre science et religion // Science et Pseudo-Sciences. 2015. № 314. P. 41-45.

Charfi 2015 - Charfi F.F. Science et religions: refuser les confusions // Science et Pseudo-Sciences. 2015. № 314. P. 35-40.

Cruz web - Cruz H. Religion and Science [Stanford Encyclopedia of Philosophy. 2017] // https:// plato.stanford.edu/entries/religion-science (date of access: 14.02.2020).

Delecroix 2015 - Delecroix $V$. Introduction Philosophie et religion // Archives de sciences sociales des religions. 2015. № 169. P. 13-19. DOI: https://doi.org/10.4000/assr.26602.

Fakler web - Fakler $R$. Passen Wissenschaft und Christentum zusammen? 2018// http:// rolandfakler.de/wissenschaft-und-christentum.

Freistetter web-Freistetter F. Wissenschaft und Religion vertragen sich einfach nicht. $2011 / / \mathrm{http} / /$ scienceblogs.de/astrodicticum-simplex/2011/10/ 13 /wissen schaft-und-religion-vertragensich-einfach-nicht.

Jolibert web - Jolibert B. Science, religion, philosophie: une confrontation salutaire. 2001 // https://hal.univ-reunion.fr/hal-02406288.

Truc 2018 - Truc J-P. «Yves Gingras, L'Impossible dialogue. Sciences et religions»// Questions de communication. 2018. № 33. P. 429-431.

\section{REFERENCES}

Aleksander D.R., 2010. Models of the Relationship Between Religion and Science. Stranitsy: Bogoslovie. Kultura. Obrazovanie, vol. 14, no. 2, pp. 274-286.

Sokolov V.V. et al. (eds.), 1969. Anthology of World Philosophy. In 4 vols. Vol. 1, pt. 2. Moscow, Mysl Publ.

Antonov K., 2015. Philosophical Rationality Between Religion and Science: Russian Hegelianism of the Late $19^{\text {th }}$ century (B.N. Chicherin and
P.A. Bakunin). Gosudarstvo, religiya, tserkov v Rossii i za rubezhom, no. 4 (33), pp. 110-134.

Bobrova L.A., 2010. Dialogue of Religion with Science and Philosophy (Abstract Review). Vy'khristyuk-Andreeva I.S. (ed.). Znanie i vera v filosofskom diskurse: traditsii i sovremennost: sb. nauch. tr. Moscow, RAN, INION, pp. 11-34.

Gegel' G.V.F., 1974. Hegel's Speech Delivered at the Opening of the Readings in Berlin on October 22, 1818. Entsiklopediya filosofskikh nauk. In 3 vols. Vol. 1. Nauka logiki. Moscow, Mysl Publ., pp. 79-83.

Gizha A.V., 2018. The Question of Genesis of Philosophic Knowledge as Immanent Problematicity of Theoretical Rationality. Virtus: Scientic Journal, no. 33, pt. 1, pp. 19-24.

Zhilina V.A., 2009. Ontological Analysis of Religion in Relation to the Ideological Noprocesses of Public Consciousness. Vestnik ChelGU, no. 18, pp. 20-25.

Meretukova Z.K., Chinazirova A.R., 2016. Paranaural (Esoteric) Knowledge as a Phenomenon Converging Science and Religion and the Problem of Its Inclusion in the Content of Education. Khvatova S.I. (ed.). Bogosluzhebnye praktiki $i$ kultovye iskusstva $v$ polietnicheskom regione: sb. materialov Mezhdunar. nauch. konf. Majkop, Magarin Oleg Petrovich Publ., pp. 784-801.

Nietzsche F., 1990. Menschliches, Allzumenschliches: Ein Buch für freie Geister. Nietzsche F. Sobranie sochinenij. In 2 vols. Vol. 1. Moscow, My'sl' Publ., pp. 301-302.

Nietzsche F.,1994. Untimely Thoughts. Nietzcshe F. Sobranie sochinenij. In 3 vols. Vol. 2. Moscow, Refl-book Publ., pp. 7-79.

New philosophical encyclopedia. In 4 vols. Vol. 1, $A-D, 2010$. Moscow, Mysl Publ.

Popov A.V., 2010. The Question of the Existence of God in Religion and Science. Sistema tsennostey sovremennogo obshchestva, no. 16, pp. 56-60.

Trig R., 2011. Does Science Need Religion? Stranitsy: Bogoslovie. Kultura. Obrazovanie, vol. 15, no. 2, pp. 287-296.

Whitehead A., 1990. Selected Philosophy Works. Moscow, Progress Publ.

Konstantinova F.V. (ed.). Philosophical Encyclopedia. In 5 vol. Vol. 1, 1960. Moscow, Sovetskaya entsiklopediya Publ., pp. 425-426.

Fragments of the Early Greek Philosophers. Part I. From Epic Cosmogonies to the Emergence of Atomism, 1989. Moscow, Nauka Publ.

Bricmont J., 2015. Science, philosophie, religion: quels rapports? Science et Pseudo-Sciences, no. 314, pp. 24-34.

Brosseau O., Baudouin C., 2015. La fondation Templeton ou l'imposture du dialogue entre 
science et religion. Science et Pseudo-Sciences, no. 314, pp. 41-45.

Charfi F.F., 2015. Science et religions: refuser les confusions. Science et Pseudo-Sciences, no. 314, pp. 35-40.

Cruz H., 2017. Religion and Science. Stanford Encyclopedia of Philosophy. URL: https:// plato.stanford.edu/entries/religion-science (accessed 14 February 2020).

Delecroix V., 2015. Introduction-Philosophie et religion. Archives de sciences sociales des religions, no. 169, pp.13-19. DOI: https://doi.org/10.4000/ assr.26602.

Fakler R., 2018. Passen Wissenschaft und Christentum zusammen? URL: http://rolandfakler.de/ wissenschaft-und-christentum (accessed 5 February 2020).

Freistetter F., 2011. Wissenschaft und Religion vertragen sich einfach nicht. URL: http:// scienceblogs.de/astrodicticum-simplex/2011/10/ 13/wissenschaft-und-religion-vertragen-sicheinfach-nicht/ (accessed 15 February 2020).

Jolibert B., 2001. Science, religion, philosophie: une confrontation salutaire. URL: https://hal.univreunion.fr/hal-02406288 (accessed 16 February 2020).

Truc J-P., 2018. Yves Gingras, L'Impossible dialogue. Sciences et religions. Questions de communication, no. 33, pp. 429-431.

\section{Information About the Author}

Andrew V. Gizha, Candidate of Sciences (Philosophy), Associate Professor, Department of Philosophy, Donetsk National Technical University, Artema St, 58, 283001 Donetsk, 19andrey06@mail.ru, SPIN 3654-0730, https://orcid.org/0000-0002-7823-0602

\section{Информация об авторе}

Андрей Владимирович Гижа, кандидат философских наук, доцент кафедры философии, Донецкий национальный технический университет, ул. Артема, 58, 283001 г. Донецк, 19andrey06@mail.ru, SPIN 3654-0730,https://orcid.org/0000-0002-7823-0602 